\title{
ALAT PENGAMAN KANDANG BERBASIS MIKROKONTROLER ARDUINO UNO
}

\author{
Wire Bagye1, Tsurayya Azizah² \\ Teknik Informatika, STMIK Lombok \\ Jln. Basuki Rahmat No. 105 Praya Lombok Tengah 83511 \\ wirestmik@gmail.com ${ }^{1}$, tsurayyaazizah7@gmail.com ${ }^{2}$
}

\begin{abstract}
The occurrence of theft is often in the chicken coop, the impact of this theft is that farmers experience material losses so that the farmer is no longer raising chickens. security system applied by the owner of the cage by way of patrolling at night. even though the patrol has been carried out, there are still frequent thefts because thieves are lurking in patrol activities, theft occurs when the owner of the house is unaware. a tool that is able to provide information that there are people who enter the cage to owners who work indefinitely.

The analytical method that will be used in this study is the SWOT method (Strength, Weakness, Opportunity, Threat). This method is used by researchers to collect information and conduct needs analysis. To solve the problem, a safety device with Arduino was built, a pir sensor, an 800L SIM. The enclosure safety device works to detect human body heat with the PIR Motion sensor, if there is a human crossing the Arduino sensor area it gives a signal to the 800L SIM to send a message to the cellphone owner's cellphone. The message informs that there are humans in the chicken coop.

The Result showed that $100 \%$ of case can be sent by Alat Pengaman Kandang Ayam Berbasis Mikrokontroler Arduino, namely from 70 attempts to produce 70 messages to cellphone owners with vulnerable time of 3 seconds.
\end{abstract}

Keyword : Security, , arduino uno, SIM 800L, SWOT

\begin{abstract}
Abstrak
Sering terjadinya pencurian dikandang ayam walaupun pemilik ayam melakukan penjagaan. dampak dari pencurian ialah kerugian finansial. Pencurian terjadi pada saat pemilik kandang lengah. diperlukan alat yang mampu memberikan informasi bahwa ada orang yang masuk ke kandang kepada pemilik yang bekerja dengan waktu tak terbatas.

Metode analisis yang akan digunakan dalam penelitian ini adalah metode SWOT (Strength, Weakness, Opportunity, Threat). Metode ini digunakan oleh peneliti untuk mengumpulkan Informasi dan analisa kebutuhan. Untuk menyelesaikan permasalahan maka dibangun Alat Pengaman dengan arduino, pir sensor, SIM 800L. Alat pengaman kandang bekerja mendeteksi panas tubuh manusia dengan sensor PIR Motion, jika ada manusia melintasi area sensor arduino memberikan sinyal ke SIM 800L untuk mengirim pesan ke handphone pemilik kandang. Pesan tersebut menginformasikan bahwa ada manusia di kandang ayam.

Dari hasil pengujian menunjukkan bahwa 100\% Alat Pengaman Kandang Ayam Berbasis Mikrokontroler Arduino uno mampu mengirim informasi kandang yaitu dari 70 kali percobaan menghasilkan 70 pesan ke handpone pemilik kandang dengan rentan waktu 3 detik.
\end{abstract}

Kata kunci : Pengaman, arduino uno, SIM 800L, SWOT

\section{Pendahuluan}

Seiring dengan perkembangan zaman dan teknologi kebutuhan informasi yang cepat sangat dibutuhkan dalam berbagai sektor kehidupan, sehingga menunjang kinerja sektor-sektor tersebut, salah satunya adalah aspek keamanan. Banyak sarana yang dirancang secara otomatis untuk membantu kegiatan manusia dalam mengatur keamanan lingkungan ataupun ruangan 
yang memerlukan tingkat pengamanan yang lebih ketat.

Kemajuan teknologi elektronika turut membantu dalam pengembangan sistem keamanan yang handal. Salah satunya aplikasi sistem keamanan untuk pengaman kandang ayam. Banyak alat-alat elektronika yang digunakan untuk sistem keamanan kandang ayam contohnya seperti alat pendeteksi adanya pencuri. Alat yang dijual pun begitu banyak versinya, baik dari segi kualitas, merk, dan harganya. Akan tetapi alat yang banyak ditemui dipasaran dijual terpisah dan harganyapun relatif lebih mahal.

Kelebihan utama sistem keamanan yang berbasiskan Arduino dibanding sistem keamanan konvesional adalah memiliki kemampuan beroperasi terus menerus dan dapat secara otomatis terhubung dengan perangkat lain. Masalah keamanan kandang ayam ini dapat diatasi dengan sebuah sistem keamanan yang dapat memberitahukan kepada pemilik rumah melalui notifikasi panggilan audio ketika sensor pyroelectric mendeteksi adanya orang yang masuk kedalam kandang ayam ketika ruangan dalam keadaan terkunci.

\section{Tinjauan Pustaka}

Budiharjo dan Milah (2015) dalam penelitiannya dengan judul Rancang Bangun Keamanan Pintu Ruangan Dengan RFID Dan Password Menggunakan Arduino Uno. Penelitian tersebut merancang dan merealisasikan suatu alat dalam miniatur yang berbasis mikrokontroler dengan hasil suatu miniatur pintu ruangan yang dapat dikendalikan dengan berbasis Mikrokontroler ATmega 328. yang bekerja dengan catuan daya yang berkisar 5 Vdc dan 12 Vdc dengan hasil RFID RDM 6300 memiliki frekuensi $125 \mathrm{kHz}$ dimana setelah dilakukan pengujian memliki jarak maksimal pembacaan $7 \mathrm{~cm}$ jika tidak ada penghalang antara antena RFID dengan Tag Card.

Ariessanti, dkk (2014) dalam penelitiannya dengan judul Rancang Bangun Peralatan Pengaman Pada Toko Perhiasan Berbasis Arduino . Penelitian tersebut bertujuan untuk merancang sebuah rancang bangun peralatan pengaman yang menyerupai display sebagai pengaman pada toko perhiasan dengan hasil peralatan pengaman dapat merespon gerak pada sensor infrared dengan maksimum adalah $80 \mathrm{~cm}$, dan bluetooth dengan jarak maksimum 8 meter, 6 meter pada ruang yang terdapat banyak benda disekitar alat.

Harjanto dan Leonardi (2017) penelitiannya dengan judul Rancang Bangun Sistem Buka Pintu Dengan Menggunakan Password Berbasis Mikrokontroller Arduino. Sistem aplikasi buka tutup pintu menggunakan kode password berbasis mikrokontroler merupakan salah satu sistem keamanan elektronis yang dirancang untuk memberikan solusi keamanan pada gedung atau bangunan. Penelitian ini merupakan hasil dari rancang bangun prototype system buka tutup pintu dengan menggunakan password berbasis mikrokontroller arduino. Pembuatan alat dilakukan sebagai salah satu usaha dalam kemajuan teknologi untuk sistem keamanan. Komponen yang digunakan dalam rancang bangun ini adalah arduino nano, Lcd 16x2, Membrane Matrix Keypad 4x3 7 input, IC 74HC595, Buzzer 5v dan motor servo. Sedangkan software yang digunakan yaitu fritzing dan arduino ID, Berdasarkan hasil pengukuran dan pengujian, sistem pada alat dibuat mampu membuka menutup pintu otomatis menggunakan password. Pintu dapat membuka selama 15 detik dan menutup kembali dalam keadaan ruang terbuka.

Silvia, dkk (2014), judul penelitiannya Rancang Bangun Akses Kontrol Pintu Gerbang Berbasis Arduino Dan Android. Penelitian ini tentang rancang bangun prototype perangkat sistem pengendali pintu gerbang otomatis berbasis Arduino dan sistem operasi Android. Pembuatan alat dilakukan sebagai salah satu usaha dalam kemajuan teknologi untuk memberikan kemudahan dan kenyamanan melalui pengembangan sistem otomasi pada rumah berupa pintu gerbang otomatis. Komponen yang digunakan untuk perancangan sistem adalah modul mikrokontroler Arduino Uno R3, Modul Bluetooth HC-05, Sensor getar Piezoelektrik, Motor DC, Power Bank dengan kapasitas 5600 mAh dan telepon pintar berbasis Android versi 4.2.1, sedangkan perancangan software menggunakan Arduino IDE, Android SDK dan Eclipse IDE. Berdasarkan hasil pengukuran dan pengujian, sistem pada alat yang dibuat mampu membuka dan menutup pintu gerbang secara otomatis pada jarak maksimum 11 meter dengan waktu respon maksimum 1 detik dalam keadaan ruang terbuka. 
Saputra (2015), dengan judul penelitian Perancangan Smart Home Berbasis Arduino Dalam penelitian ini pembahasan perancangan Modul Smart Home menggunakan mikrokontroler Arduino dan cara berkomunikasi dengan computer, perancangan modul alarm dan catu daya yang digabungkan menjadi satu, perancangan modul driver motor stepper, perancangan modul optikal encoder untuk menentukan posisi kamera, dan perancangan aplikasi untuk merekam keadaan rumah dengan webcam, perancangan program interface modem sehingga dapat mengirim Panggilan automatis.

Penelitian ini bertujuan untuk menguji alat keamanan kandang ayam berbasis mikrokontroler arduino uno dengan maksud jikalau ada pergerakan manusia maka sensor akan membacanya kemudian alat ini akan mengirimkan pesan ke pemiliknya.

Perbedaan hasil penelitian ini dengan penelitian sebelumnya yaitu perancangan alat pendeteksi gerak menggunakan arduino uno dan mini pir sensor dan menggunakan handphone yang bisa. Berdasarkan hasil pengukuran dan pengujian, sistem pada alat yang dibuat mampu mendeteksi gerak dengan jarak maksimum sampai 7 meter dan lebar 5 meter dan waktu pengiriman pesan selang 3 detik dengan penyebaran $120^{\circ}$. Perancangan alat ini untuk mendeteksi gerak yang ada di dalam kandang dengan pengiriman pemberitahuan melalui SMS ke handphone bukan dalam bentuk panggilan atau dalam bentuk Video.

\section{Metodologi Penelitian}

Dalam penelitian ini dilakukn beberapa tahapan penelitian seperti tergambar dalam flowmap gambar 3.1

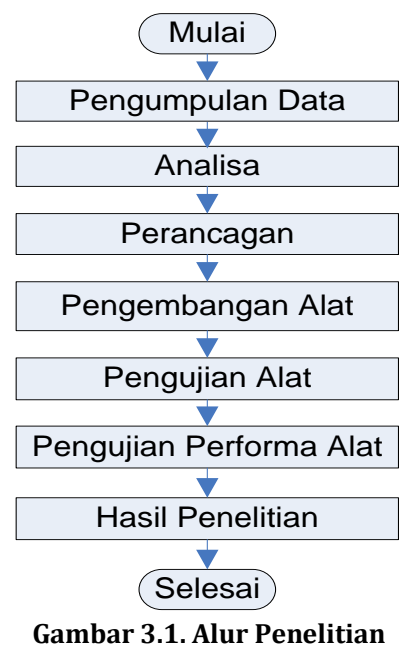

\subsection{Pengumpulan Data}

1. Observasi

Pengumpulan data dilakukan dengan melakukan pengamatan langsug dengan tilik mata kandang ayam peternak ayam oleh peneliti untuk mendapatkan sketsa area permasalahan.

\section{Wawancara}

Tanya jawab kepada pemilik kandang ayam tentang permaslahan yang dihadapi dan menggali informasi ain terkait penelitian ini.

3. Studi Pustaka

untuk mencari teori dan informasi yang berhubungan dengan topik penelitian ini. Informasi diperoleh melalui buku-buku, literasi internet, dan hasil penelitian maupun karya ilmiah. Analisis Aplikasi Sejenis Mencari informasi tentang rancang bangun alat pengaman berbasis mikrokontroler Arduino uno dengan topik dan membandingkan jenis dan manfaat.

\subsection{SWOT}

Metode Analisis yang digunakan dalam penelitian ini adalah metode SWOT (Strength, Weakness, Opportunity, Threat). Metode ini digunakan oleh peneliti untuk mengumpulkan Informasi dalam merancang aplikasi rancang bangun pengaman berbasis mikrokontroler Arduino uno. Informasi yang didapat selanjutnya dikelompokkan menjadi empat indikator yaitu kekuatan, kelemahan, peluang dan hambatan. Analisis SWOT merupakan alat kerangka kerja berdasarkan manajemen berbasis nilai dan strategi formulasi dengan mengenali empat indikator tersebut. 


\subsection{Perancangan Alat}

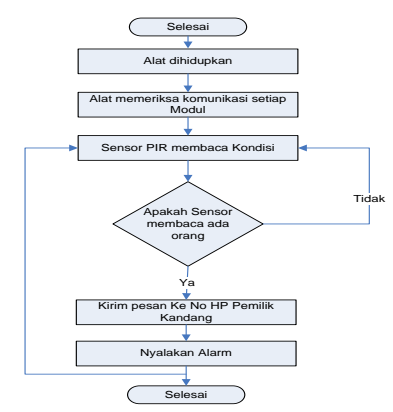

Gambar 3.2. Flowchart rancangan kerja alat

Perancangan alat pengaman dilakukan berdasarkan kebutuhan lapangan yaitu alata dapat memberikan informasi kepada pemilik kandang saat ada orang yang masuk kekandang ayam. Alur kerja alat ditunjukkan oeh flowchart gambar 3.2.

\subsection{Pengembangan Alat}

Metode pengembangan menggunakan metode Prototype. Pengembangan ini merupakan rancang bangun yang bertujuan untuk mendapatkan rancangan atau prototipe peralatan keamanan kandang ayam dan mengetahui kelayakan prototipe ini. Keamanan pada kandang ayam dirancang melalui tahapan : analisa kebutuhan, desain blok diagram keamanan pada kandang ayam dan pengujian.

Tahap pengembangann alat proses memaparkan hasil hasil dari instalasi perangkat keras, langkah-langkah instalasi perangkat lunak, dan pengujian. Kemudian hasil dari uji coba tersebut dievaluasi. Apabila terdapat kesalahan atau kekurangan tersebut, maka dapat dilakukan perbaikan yang diperlukan.

Perakitan modul dilakukan dengan menghubungkan modul Arduin Uno, Sensor PIR Motion, dan SIM800. Perakitan alat ditunjukkan oleh gambar 4.1.

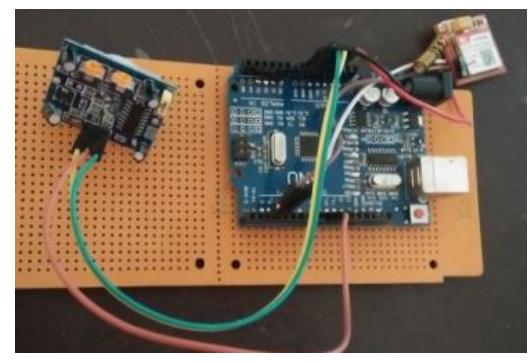

Gambar 3.3. Perakitan Alat
Langkah selanjutnya ialah melakukan pemrograman pada Arduino uno sebagai otak dari alat pengaman. Pemrograman dan upload kode hex ke modul Arduino Uno menggunakan aplikasi arduino uno.

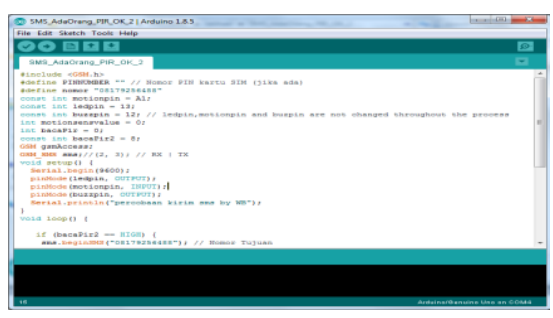

Gambar 3.4. Pemrograman Arduino

\section{Hasil dan Pembahasan}

\subsection{Simulasi Alat}

Pengujian pertama dilakukan dengan simusi program Arduino dengan menghubungkan ke port USB. Pengamatan hasil mendeteksi gerakan didalam ruangan dilihat dari monitor serial yang ada pada software arduino, pengujian ini berfungsi untuk menguji kemampuan alat mengirim pesan ke handphone.

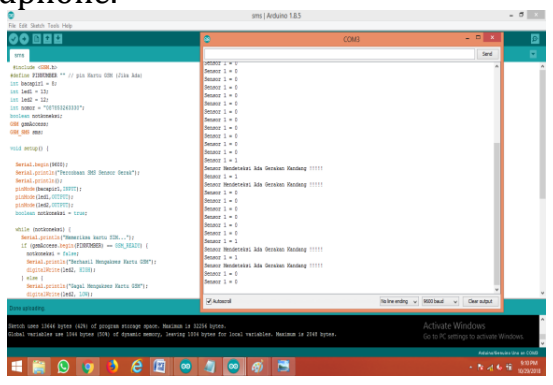

Gambar 4.2. Pengujian pada Aplikasi Arduino

Pengujian alat ini dilakukan dengan mengaktifkan alat pada ruang yang kosong dari manusia dan hewan. Hal ni dilakukan untuk menguji respon alat pada saat belum ada pergerakan manusia atau hewan sebagai sumber panas yang akan dideteksi oleh sensor PIR Motion. Hasil pengujian menunjukkan bahwa saat belum ada pergerakan tidak ada pesan masuk pada handphone tujuan. 


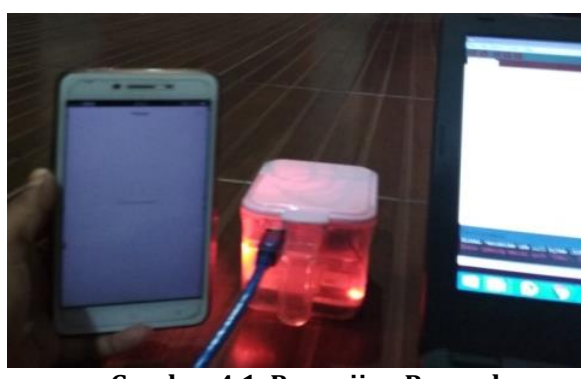

Gambar 4.1. Pengujian Ruang kosong

Pengujian selajutnya ialah mengamati respon alat terhadap pergerakan manusia sebagai pengganti pencuri. Hasil pengujian menunjukkan respon alat mampu mengirim Pesan ke nomor handphone.

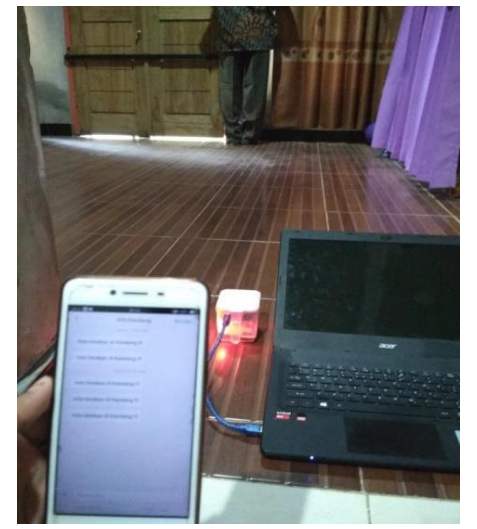

Gambar 4.2. Pengujian respon sensor

\subsection{Pengujian Lapangan}

Pengujian dilakukan dikandang sebelum ada gerakan dan sensor tidak mendeteksi adanya pergerakan sehingga tidak ada pesan masuk ke a

Gambar 4.3. Pengujian Lapangan

Gambar 4.3b. menunjukkan setelah ada orang jarak 3 meter alat berhasil mendeteksi adanya

ISSN. 2620-6900 (Online) 2620-6897 (Cetak) pergerakan sehingga alat mengirimkan pesan masuk kehandphone

\section{Kesimpulan dan Saran}

Kesimpulan hasil pengujian menunjukkan bahwa $100 \%$ alat pengaman kandang berbasis mikrokontroler Arduino Uno mampu mengirim informasi kandang yaitu dari 20 kali percobaan menghasilkan 20 pesan ke handpone pemilik kandang.

Saran untuk penelitian selanjutnya dapat menambahkan fitur dari pengaman ini dengan kemmpuan perintah menghidupkan dan mematikan fungsi alat dengan perintah SMS, menambahkan sensor selain PIR, dan desain case yang portable.

\section{Daftar Pustaka :}

[1] Apriliana, D., Sadnowo, A., \& Fitriawan, H. (2013). Perangkap Tikus Dengan Fasilitas Short Message Service (SMS) Menggunakan Mikrokontroller ATmega8535. Jurnal Informatika dan Teknik Elektro Terapan, $1(2)$.

[2] Ariessanti, H. D., \& Munzilin, R. (2015). Rancang Bangun Peralatan Pengaman Pada Toko Perhiasan Berbasis Arduino. CCIT Journal, 8(3), 165-173.

[3] Bagye, W. (2018). Implementasi Jalur Komunikasi Global System Mobile (GSM) Untuk Kontrol Robot Jarak Jauh Berbasis Mikrikontroller Atmel89S52. Jurnal Informatika dan Rekayasa Elektronik, 1(1), 16.

[4] Budiharto, W. (2011). Aneka Proyek Mikrokontroler. Yogyakarta: Graha Ilmu.

[5] Budiharjo, S., \& Milah, S. (2014). Keamanan Pintu Ruangan Dengan Rfid Dan Password Menggunakan Arduino Uno. J. ICT Penelit. dan Penerapan Teknol, 28-34.

[6] Djuandi, F. (2011). Pengenalan Arduino. Ebook. www. tobuku, 1-24.

[7] Fitriastuti, F., \& Prasetyo, A. A. (2013). Sistem Otomatisasi pemberian minum ayam ternak berbasis mikrokontroler AT89s52. Jurnal. Jurusan Teknik Infomatika, Fakultas Teknik, Universitas Janabadra. Yogyakarta. 
[8] Harjanto, A., \& Leonardi, Y. C. (2018, January). Rancang Bangun Sistem Buka Pintu Dengan Menggunakan Password Berbasis Mikrokontroller Arduino. In Prosiding Seminar Nasional Teknologi, Inovasi dan Aplikasi di Lingkungan Tropis (Vol. 1, No. 1, pp. 39-44).

[9] Prakasa, G. A., \& Eng, M. (2017). Prototype Sistem Kunci Pintu Berbasis QRCode dan Arduino (Doctoral dissertation, Universitas Muhammadiyah Surakarta).

[10] Saputra, Z. R. (2016). Perancangan Smart Home berbasis Arduino. Amik Sigma Palembang.

[11] Silvia, A. F., Haritman, E., \& Mulyadi, Y. (2014). Rancang Bangun Akses Kontrol Pintu Gerbang Berbasis Arduino Dan Android. Electrans, 13(1), 1-10.
[12] Ramadhan, A. S., \& Handoko, L. B. (2016). Rancang Bangun Sistem Keamanan Rumah Berbasis Arduino Mega 2560. Techno. com, 15(2), 117-124.

[13] Utama, F. P., Anggriani, K., \& Setiawan, Y. (2015). Rancang Bangun Sistem Informasi Pemantau Transportasi Zat Radioaktif Dengan Input SMS Terenkripsi Dan Nonenkripsi (Studi Kasus: Batan YOGYAKARTA). Pseudocode, 2(2), 115-123.

[14] Winardi, S., \& Firmansyah, W. A. K. Rancang bangun sistem pengaman pintu rumah menggunakan android berbasis arduino uno. 